\title{
FAKTOR-FAKTOR PRODUKSI
}

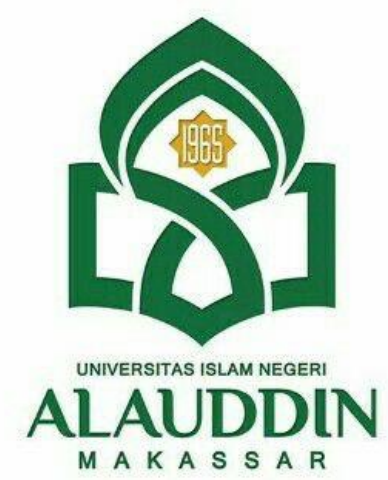

MAKALAH

Pada Mata Kuliah Pengantar Ekonomi Program Studi

Ekonomi Islam Semester 1 Tahun 2021

Oleh:

Wahyuni Putrisarira

NIM.90100121117

Dosen Pengajar:

Sijaruddin, ME

PROGRAM STUDI EKONOMI ISLAM

FAKULTAS EKONOMI DAN BISNIS ISLAM

UIN ALAUDDIN MAKASSAR

2021 
KATA PENGANTAR

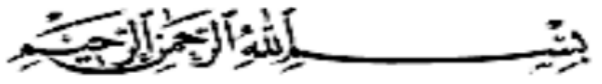

Puji syukur penulis panjatkan ke hadirat Allah Swt. atas rahmat dan hidayahNya sehingga penyusunan tesis ini dapat diselesaikan. Shalawat dan salam semoga tercurahkan kepada Nabi Muhammad Saw keluarga dan para sahabatnya. Makalah dengan judul: "faktor-faktor produksi" ini dimaksudkan untuk menyelesaikan tugas pada mata kuliah pengantar ekonomi. Penulis menyadari bahwa penyelesaian tesis ini tidak akan terwujud tanpa bantuan, bimbingan dan dukungan dari berbagai pihak.

Makassar, 05 Oktober 2021

Penyusunan 


\section{DAFTAR ISI}

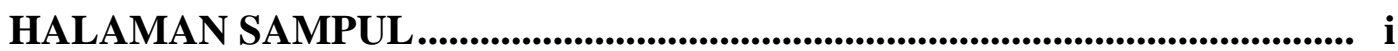

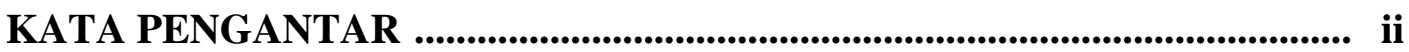

DAFTAR ISI..................................................................................................... ii
A. Latar Belakang
1
B. Rumusan Masalah ........................................................................... 2

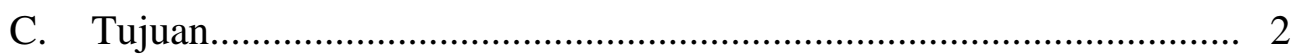

BAB II PEMBAHASAN ...................................................................................... 3

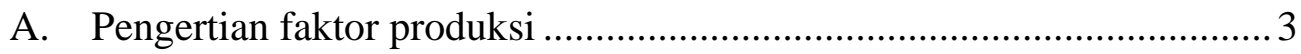

B. Jenis faktor produksi .................................................................... 4

BAB III PENUTUP ......................................................................................................... 9

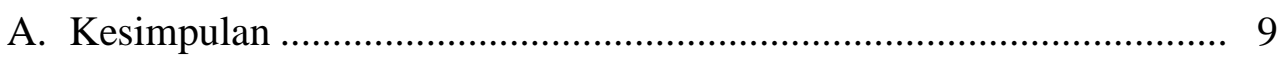

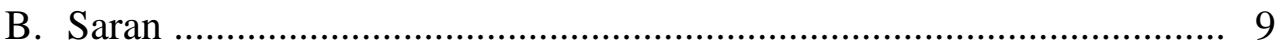

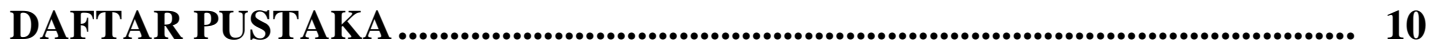




\section{BAB I \\ PENDAHULUAN}

\section{A. Latar Belakang}

Produksi merupakan pusat pelaksanaan kegiatan yang konkrit bagi pengadaan barang dan jasa pada suatu badan usaha dan perusahaan. Proses produksi merupakan bagian terpenting dalam perusahaan, karena apabila berhenti maka perusahaan akan mengalami kerugian. Dalam kegiatan produksi, karyawanlah yang melaksanakan proses produksi. Karyawan pada hakikatnya merupakan salah satu unsur yang menjadi sumber daya dalam perusahaan. Kegiatan produksi bagi sebuah perusahaan bukan sesuatu yang mudah untuk dikerjakan. Banyak sekali yang harus diperhatikan agar proses produksi dapat berjalan dengan baik. Terlebih jika perusahaan tersebut dituntut untuk dapat memenuhi semua permintaan konsumen dengan tenggang waktu yang diberikan secara efektif. Perusahaan akan semakin sulit jika dihadapkan dengan segala keterbatasan seperti waktu, tenaga kerja, dan lain-lain. Jika perusahaan memiliki keterbatasan itu perlu disusun perencanaan produksi untuk dapat memenuhi permintaan konsumen. Beberapa faktor perencanaan produksi adalah sumber daya alam, pengaturan sumber daya manusia, faktor modal (kapital), faktor informasi. Faktor ini penting agar proses produksi dapat berlangsung. Proses produksi yang berjalan dengan baik akan menghasilkan output yang baik dan sesuai dengan target produksi yang diinginkan. 


\section{B. Rumusan Masalah}

Bedasarkan latar belakang diatas dapat dirumuskan beberapa rumusan masalah, yaitu:

1. Apa pengertian faktor produksi?

2. Apa saja jenis-jenis dari faktor produksi?

\section{Tujuan}

Sejalan dengan rumusan masalah yang telah dituangkan, maka tujuan penulisan ini adalah sebagai berikut:

1. Untuk memahami pengertian dari faktor produksi.

2. Untuk mengetahu dan memahami jenis-jenis dari faktor produksi. 


\section{BAB II}

\section{PEMBAHASAM}

\section{A. Pengertian faktor produksi}

Kegiatan Produksi adalah merupakan kegiatan menciptakan atau menambah nilai guna suatu barang untuk memenuhi kebutuhan. Dimana, kegiatan menambah daya guna suatu benda tanpa mengubah bentuknya dinamakan produksi jasa Sedangkan kegiatan menambah daya guna suatu benda dengan mengubah sifat dan bentuknya dinamakan produksi barang. Dari pengertian di atas dapat disimpulkan bahwa produksi mengandung dua hal penting yaitu menciptakan nilai guna seperti membangun rumah, membuat pakaian, membuat tas, membuat sepeda, dan sebagainya. Juga menambah nilai guna seperti memperbaiki televisi, memperbaiki sepatu, memperbaiki atau memodifikasi mobil atau motor, dan lain sebagainya. Pada dasarnya, produksi bertujuan untuk memenuhi kebutuhan manusia dalam mencapai kemakmuran. Kemakmuran dapat tercapai jika tersedia barang dan jasa dalam jumlah yang mencukupi. Orang atau badan yang melakukan kegiatan produksi disebut dengan produsen. Berdasarkan pengertian tersebut maka produksi mengandung dua hal pokok, yaitu menciptakan nilai guna seperti membangun rumah, membuat pakaian, membuat tas dan membuat sepeda serta menambah nilai 
guna seperti memperbaiki televisi, memperbaiki sepatu dan memperbaiki atau memodifikasi mobil/motor.

\section{B. Jenis faktor produksi}

Untuk menambah nilai guna dalam sebuah barang dan/atau jasa, tentu harus ada faktor-faktor pendukungnya.Hal ini bertujuan untuk mencapainya nilai guna yang diinginkan. Lalu, faktor apa saja yang mendukung proses produksi ini?

1. Sumber Daya Alam (SDA)

Seperti yang sudah sama-sama kita ketahui, faktor SDA ini merupakan segala sesuatu yang disediakan oleh alam dan dapat dimanfaatkan manusia dalam usahanya mencapai kemakmuran misalnya lingkungan alam, lahan, maupun kekayaan yang terkandung di dalam tanah. Sumber daya alam seperti

- Udara, tanah, air dan sinar matahari.

- Hewan dan tumbuhan.

- Mineral dan bahan tambang lainnya. 
2. Sumber Daya Manusia (SDM)

SDM atau Sumber Daya Manusia juga menjadi salah satu faktor yang mendorong tercapainya proses produksi. Di mana, SDM merupakan kemampuan (daya) atau usaha manusia berupa jasmani maupun rohani yang digunakan untuk meningkatkan guna suatu barang. Menurut kualitasnya, SDM dibedakan menjadi tiga yaitu:

- Tenaga kerja terdidik, tenaga kerja yang memerlukan pendidikan formal untuk dapat melaksanakan pekerjaannya. Contohnya dokter, arsitek serta dosen.

- Tenaga kerja terampil, tenaga kerja yang memerlukan keterampilan khusus agar bisa melaksanakan pekerjaannya. Contohnya penjahit, tukang, supir dan kapster salon.

- Tenaga kerja tidak terdidik dan tidak terlatih, tenaga kerja yang tidak membutuhkan pendidikan atau pelatihan tertentu agar bisa melakukan pekerjaannya. Contohnya asisten rumah tangga, kuli bangunan dan petugas kebersihan.

Sementara itu, menurut sifat pekerjaannya, dapat dibedakan menjadi : 
- Tenaga kerja jasmani, tenaga kerja yang mengandalkan tenaga untuk melaksanakan pekerjaannya. Contohnya petugas kebersihan, tukang becak dan kuli angkut.

- Tenaga kerja rohani, tenaga kerja yang mengandalkan pikiran dan perasaan dalam melaksanakan pekerjaannya. Contohnya dosen, guru, seniman dan psikolog.

3. Sumber Daya Modal

Faktor selanjutnya adalah sumber daya modal yang menjadi alat atau barang jadi. Sumber daya ini akan digunakan sebagai sarana untuk menghasilkan barang. Dimana, modal ini harus dimiliki produsen atau Anda sebagai pemilik perusahaan, dan tidak harus berbentuk uang. Modal yang dihasilkan bisa berupa alat-alat produksi seperti gedung, mesin, dan bahan dasar yang digunakan dalam proses produksi. Modal adalah salah satu faktor penting untuk pengelolaan biaya produksi dalam sebuah perusahaan. Berdasarkan Sifatnya:

- Modal tetap, modal yang dapat dipakai secara berulang-ulang. Contohnya bangunan, mesin dan peralatan.

- Modal lancar, modal yang akan habis digunakan dalam setiap proses produksi. Contohnya bahan baku untuk produksi.

Berdasarkan Sumbernya: 
- Modal sendiri, modal yang sumbernya berasal dari perusahaan sendiri.

- Modal asing, modal yang sumbernya berasal dari luar perusahaan.

Berdasarkan Kepemilikannya:

- Modal individu, modal yang berasal dari perorangan dimana hasilnya akan menjadi sumber penghasilan bagi pemiliknya.

- Modal publik, modal yang berasal dari pemerintah dimana hasilnya akan digunakan untuk kepentingan masyarakat umum.

Berdasarkan Bentuknya:

- Modal konkret, modal yang dapat dilihat secara nyata dalam kegiatan produksi. Contohnya bangunan, mesin, peralatan dan kendaraan.

- Modal abstrak, modal yang tidak terlihat secara nyata tapi bernilai bagi perusahaan. Contohnya hak merek, hak paten dan nama baik perusahaan.

4. Keahlian

Keahlian menjadi salah satu faktor terpenting dalam menjalankan proses kegiatan produksi. Di mana, keahlian atau keterampilan individu penting untuk mengoordinasikan dan mengelola faktor produksi dalam menghasilkan barang 
dan jasa. Keahlian atau keterampilan individu penting untuk mengkoordinasikan dan mengelola faktor produksi dalam menghasilkan barang dan jasa. Beberapa keahlian yang diperlukan seperti perencanaan (planning), pengorganisasian (organizing), penggerakan (actuating) dan pengawasan (controling).

\section{Sumber Daya Informasi}

Kemajuan teknologi informasi berperan besar dalam kegiatan produksi. Ini meliputi keseluruhan informasi dan data yang diperlukan oleh perusahaan untuk mengoperasikan bisnis. Beberapa informasi seperti prediksi kondisi pasar di masa depan, data, informasi ekonomi, pengetahuan karyawan dan lainlain. Mengetahui informasi jumlah persediaan stok barang juga sangat penting dalam proses produksi, maka akan lebih baik jika Anda memiliki aplikasi stok barang online maupun aplikasi stock opname yang dapat membantu hal ini. 


\section{BAB III}

\section{PEMBAHASAN}

\section{A. Kesimpulan}

itulah tadi pengertian dan jenis faktor yang produksi berperan dalam pengembangan bisnis. Keberadaan faktor produksi menjadi hal yang harus disiapkan secara matang oleh pelaku usaha dalam perencanaan bisnisnya. Hal itu akan mempermudah pelaku bisnis untuk menyiapkan atau menyusun strategi bisnisnya ke depan. Terlebih, keberadaan faktor produksi juga menentukan kualitas produk atau jasa yang nanti dihasilkan suatu usaha.

\section{B. Saran}

Tentunya saya sadar bahwa masih banyak kekurangan yang saya miliki, baik dari tulisan maupun bahasan yang kami sajikan, oleh karena itu mohon di berikan sarannya agar saya bisa membuat makalah lebih baik lagi. Dan semoga makalah ini bisa bermanfaat bagi kita semua, dan menjadi wawasan kita dalam memahami pengertian dan jenis-jenis dari faktor produksi. 


\section{DAFTAR PUSTAKA}

https://www.jurnal.id/id/blog/jelaskan-pengertian-contoh-kegiatan-proses-

produksi-adalah/\#Apa_itu_Pengertian_Proses_Produksi

https://www.ekrut.com/media/faktor-produksi

https://www.cekkembali.com/faktor-produksi/ 
